\title{
Base Compositions and Homologies of Deoxyribonucleic Acids of Corynebacteria Isolated from Human Leprosy Lesions and of Related Microorganisms
}

\author{
P. DANHAIVE, P. HOET, AND C. COCITO \\ Department of Microbiology and Molecular Genetics, Institute of Cellular and Molecular Pathology, and \\ University of Louvain Medical School, Brussels 1200, Belgium
}

\begin{abstract}
The deoxyribonucleic acids (DNAs) of 25 strains of leprosy-derived corynebacteria (LDC)-non-acid-fast, gram-positive bacteria independently isolated from human leprosy lesions and propagated in axenic culture-were purified and analyzed. The guanine plus cytosine content, by buoyant density determination, was 54 to $59 \mathrm{~mol} \%$ for most LDC strains, a range that corresponds to that (50 to 60 mol\%) of corynebacteria which multiply in animal cells. These values were checked by chromatographic analyses of acid digests of the DNAs. The taxonomic position of the LDC as determined by DNA base composition was confirmed by the results of the corynomycolic acid determinations of the cell walls of the LDC. The results of the hybridization of the DNAs from the LDC strains suggest the occurrence of two high-homology groups, in which most of the strains were accommodated. In contrast, little homology was observed between the DNAs of the LDC and the reference corynebacteria employed. From these data, it can be inferred that the LDC represent a homogeneous and unique cluster of organisms within the genus Corynebacterium, more specifically within the group of corynebacteria pathogenic for humans.
\end{abstract}

In addition to Mycobacterium leprae-an acid-fast, gram-positive bacterium which cannot be propagated in vitro-other microorganisms, referred to as "diphtheroids" or "coryneforms," have been recognized in human leprosy lesions $(2,10,11)$. The latter gram-positive bacteria, which are not acid fast and which multiply in axenic culture, were tentatively identified as corynebacteria on the basis of the structure of their cell envelopes, in particular, on the basis of the presence of corynomycolic acid in the cell walls (14)-hence, the proposal by Barksdale (2) to designate these organisms as leprosy-derived corynebacteria (LDC). However, immunochemical studies showed that ribosomes isolated from LDC strains cross-reacted with antisera against mycobacteria rather than with antisera against corynebacteria (15).

In the present work, the deoxyribonucleic acids (DNAs) of 25 independently isolated LDC were purified. Although the initial preparations gave DNAs with abnormally low guanine-pluscytosine $(G+C)$ values, because of the presence of tightly bound polypeptides, pure LDC DNAs were obtained by improving the purification procedure. The base contents of the purified DNAs were determined to establish with greater precision the taxonomic position of the LDC. In addition, DNA hybridization experiments were carried out to assess the genetic homogeneity of this group of microorganisms and to determine their relationship, if any, to the reference corynebacteria studied.

\section{MATERIALS AND METHODS}

Bacterial strains. The LDC strains were isolated from leprosy patients of different countries; they were obtained through the courtesy of J. Delville (University of Louvain Medical School, Brussels, Belgium), and details concerning their origin are reported in Table 1. Reference strains of Corynebacterium species were obtained from the National Collection of Type Cultures, London, England and the National Collection of Plant Pathogenic Bacteria, Harpenden, England.

Cultivation. $\mathrm{LDC}$ were grown at $37^{\circ} \mathrm{C}$ under forced aeration in a medium containing (per liter): Casitone (Difco Laboratories, Detroit, Mich.), $25 \mathrm{~g} ; \mathrm{FeNH}_{4}$ citrate, $0.05 \mathrm{~g} ; \mathrm{Na}_{2} \mathrm{HPO}_{4} \cdot 2 \mathrm{H}_{2} \mathrm{O}, 3.14 \mathrm{~g} ; \mathrm{KH}_{2} \mathrm{PO}_{4}, 1 \mathrm{~g}$; $\mathrm{MgSO}_{4} \cdot 7 \mathrm{H}_{2} \mathrm{O}, 0.01 \mathrm{~g}$; sodium succinate $6 \mathrm{H}_{2} \mathrm{O}, 7 \mathrm{~g}$; $\mathrm{NH}_{4} \mathrm{Cl}, 5 \mathrm{~g} ; \mathrm{MgCl}_{2} \cdot 6 \mathrm{H}_{2} \mathrm{O}, 0.3 \mathrm{~g} ; \mathrm{KHCO}_{3}, 0.5 \mathrm{~g}$, $\mathrm{ZnSO}_{4} \cdot 7 \mathrm{H}_{2} \mathrm{O}, 6 \mathrm{mg} ; \mathrm{CaCl}_{2} \cdot 4 \mathrm{H}_{4} \mathrm{O}, 1.5 \mathrm{mg}$; $\mathrm{MnCl}_{2} \cdot 4 \mathrm{H}_{2} \mathrm{O}, 1.5 \mathrm{mg} ; \mathrm{FeSO}_{4} \cdot 7 \mathrm{H}_{2} \mathrm{O}, 1.5 \mathrm{mg}$; $\mathrm{CuSO}_{4} \cdot 5 \mathrm{H}_{2} \mathrm{O}, 0.45 \mathrm{mg} ; \mathrm{CoCl}_{2} \cdot 6 \mathrm{H}_{2} \mathrm{O}, 0.48 \mathrm{mg}$; $\mathrm{Na}_{2} \mathrm{MoO}_{4} \cdot 2 \mathrm{H}_{2} \mathrm{O}, 0.75 \mathrm{mg}$; ethylenediaminetetraacetic acid (EDTA), disodium salt, $5 \mathrm{mg}$; and $5 \%$ ( $\mathrm{vol} / \mathrm{vol}$ ) horse serum. Reference corynebacteria were grown in heart infusion broth in shaken flasks either at $37^{\circ} \mathrm{C}$ (animal parasites) or at $25^{\circ} \mathrm{C}$ (plant pathogens).

DNA extraction. Bacteria harvested by centrifugation $\left(6500 \times g, 15 \mathrm{~min}, 4^{\circ} \mathrm{C}\right)$ and suspended in $0.15 \mathrm{M}$ $\mathrm{NaCl}$ plus $0.1 \mathrm{M}$ EDTA ( $\mathrm{pH}$ 8) were frozen and thawed 
TABLE 1. Designations and sources of the strains studied

\begin{tabular}{|c|c|c|c|c|c|c|}
\hline \multicolumn{2}{|c|}{ Designation $^{\alpha}$} & \multicolumn{3}{|c|}{ Origin } & \multicolumn{2}{|r|}{ Isolation } \\
\hline New (LDC) & Old & Country $^{b}$ & Leprosy stage $^{c}$ & Tissue $^{d}$ & Intermediate host & Source \\
\hline 1 & D27 & $\mathrm{Z}$ & LL & $\mathbf{s}$ & - & J. Delville (1974) \\
\hline 2 & D32 & $\mathrm{Z}$ & TT & $\mathrm{b}$ & - & J. Delville (1972) \\
\hline 3 & D40 & $\mathrm{Z}$ & BB & $b$ & - & J. Delville (1973) \\
\hline 4 & D43 & Z & TT & b & - & J. Delville (1973) \\
\hline 5 & D45 & Z & BB & s & - & J. Delville (1973) \\
\hline 6 & D52H & Z & $\mathrm{TB}$ & b & - & J. Delville (1974) \\
\hline 7 & D53 & $\mathrm{Z}$ & LL & b & - & J. Delville (1974) \\
\hline 8 & L3 & $\mathrm{Z}$ & LL & s & - & J. Delville (1971) \\
\hline 9 & L4 & $\mathrm{Z}$ & LL & $\mathrm{s}$ & - & J. Delville (1972) \\
\hline 10 & 273 & Z & TT & s & - & J. Delville (1972) \\
\hline 11 & 0122 & $\mathrm{Z}$ & LL & s & - & J. Delville (1971) \\
\hline 12 & $\mathrm{C} 3$ & V & LL & s & - & C. Cocito (1978) \\
\hline 13 & AGA & $S$ & LL & $\mathrm{s}$ & - & J. Delville (1974) \\
\hline 14 & 84 & $\mathrm{E}$ & LL & s & - & J. Delville (1972) \\
\hline 15 & 86 & E & LL & $\mathrm{s}$ & - & J. Delville (1972) \\
\hline 16 & AAIII & $\mathrm{E}$ & LL & s & - & J. Delville (1975) \\
\hline 17 & LIL & $\mathrm{P}$ & LL & s & - & C. Cocito (1975) \\
\hline 18 & KIM & $\mathrm{C}$ & $\mathbf{L L}$ & s & - & J. Delville (1975) \\
\hline 19 & MANGA & $\mathrm{K}$ & LL & s & - & J. Delville (1975) \\
\hline 20 & MEDALLE-X & $\mathrm{F}$ & & bm & - & C. Reich (1965) \\
\hline 21 & FP266 & $\mathrm{E}$ & LL & $\mathrm{s}$ & Mouse & J. Delville (1973) \\
\hline 22 & FP269 & $\mathrm{E}$ & LL & s & Mouse & J. Delville (1973) \\
\hline 23 & S.A. $\mathrm{NaOH}$ & & & s & Mouse & S. Pattyn and J. Delville (1974) \\
\hline 24 & $2628 \mathrm{LB}$ & $\mathrm{U}$ & LL & s & - & L. Barksdale (1969) \\
\hline \multirow{2}{*}{\multicolumn{5}{|c|}{$\begin{array}{l}\text { "C. herculis"e NCIB } 9694 \\
\text { "C. hoffmannii", NCTC } 231\end{array}$}} & & NCTC \\
\hline & & & & & & NCTC \\
\hline \multicolumn{5}{|c|}{ C. michiganense NCPPB 1468} & & NCPPB \\
\hline \multicolumn{5}{|c|}{ C. renale NCTC 7448} & & NCTC \\
\hline \multicolumn{5}{|c|}{ C. xerosis NCTC 9755} & & NCTC \\
\hline
\end{tabular}

${ }^{a}$ New (LDC) designation replacing the old symbols of "coryneform" isolates after their identification as true corynebacteria.

${ }^{b}$ Countries: Z, Zaïre; V, Venezuela; S, Senegal; E, Ethiopia; P, Portugal; C, Canada; K, Cameroon; F, Philippines; U, United States.

' Leprosy stages: TT, tuberculoid; TB, BB, and BL, borderline; LL, lepromatous.

${ }^{d}$ Biopsy material: s, skin lesions; b, blood; bm, bone marrow.

${ }^{e}$ Not on Approved Lists of Bacterial Names (23), not validly published since 1 January 1980, and hence without standing in bacterial nomenclature. Abbreviations: NCPPB, National Collection of Plant Pathogenic Bacteria; National Collection of Type Cultures.

three times, incubated with lysozyme and then with pronase $\left(3 \mathrm{mg} / 10^{11}\right.$ cells per $\mathrm{ml}$ for each enzyme, $37^{\circ} \mathrm{C}$, $14 \mathrm{~h}$ ), mixed with an equal volume of phenol previously saturated with $0.1 \mathrm{M} \mathrm{NaCl}$ and $0.1 \mathrm{M}$ tris(hydroxymethyl)aminomethane (Tris)-hydrochloride ( $\mathrm{pH}$ 9) containing $1 \%(\mathrm{wt} / \mathrm{vol})$ sodium dodecyl sulfate, and shaken at $4^{\circ} \mathrm{C}$ for $1 \mathrm{~h}$. After centrifugation at $6,000 \times g$ for $15 \mathrm{~min}$, the upper aqueous phase was removed, mixed with an equal volume of a chloroform-isoamyl alcohol mixture (24:1), and centrifuged at $6,000 \times g$ for $15 \mathrm{~min}$ at $4^{\circ} \mathrm{C}$. The supernatant fluid was extracted three times with diethylether and was incubated with pancreatic ribonuclease $\left(50 \mu \mathrm{g} / \mathrm{ml}, 45 \mathrm{~min}, 37^{\circ} \mathrm{C}\right)$; the chloroform-isoamyl alcohol treatment was repeated and the aqueous phase was dialyzed against $8 \mathrm{M}$ urea plus 0.24 sodium phosphate buffer ( $\mathrm{pH} 6.8$ ). Purification of the DNA was achieved by chromatography on hydroxyapatite columns by the method of Bernardi (3). Samples containing 30 to $40 A_{260}$ (absorbance at $260 \mathrm{~nm}$ ) units of DNA in the urea phosphate buffer were loaded on hydroxyapatite columns $(4 \mathrm{~cm}$ wide by
$1 \mathrm{~cm}$ high; DNA-grade Bio-Gel HTP from Bio-Rad Laboratories, Richmond, Calif.; void volume, $8 \mathrm{ml}$ ), which were washed, first with $8 \mathrm{M}$ urea plus $0.24 \mathrm{M}$ sodium phosphate buffer ( $\mathrm{pH}$ 6.8) and then with 0.14 $M$ sodium phosphate buffer ( $\mathrm{pH} 6.8$ ); the DNA was eluted with $0.48 \mathrm{M}$ sodium phosphate buffer ( $\mathrm{pH} \mathrm{6.8)}$ (19). The average yield was $1 \mathrm{mg}$ of DNA per $\mathrm{g}$ (wet weight) of cells.

Chemical and physical determinations of DNA. The purity of each DNA preparation was established by spectrophotometric determinations $\left(A_{260} / A_{280}\right.$ and $A_{260} / A_{230}$ ratios). The absence of contamination by protein and by ribonucleic acid was checked by the Folin phenol method and by the orcinol procedure (8), respectively. The $\mathrm{G}+\mathrm{C}$ content of the DNA was routinely determined from the buoyant density of the DNA in $\mathrm{CsCl}$ gradients in $0.015 \mathrm{NaCl}$ plus $0.0015 \mathrm{M}$ sodium citrate buffer, $\mathrm{pH} 8$ (18). The densities of the DNA samples were calculated by reference to standard DNA (purified double-stranded DNA of virus 2C, $\rho_{23^{\circ}}=1.742 \mathrm{~g} / \mathrm{cm}^{3}$. In most instances an analytical- 
preparative L65 ultracentrifuge (Spinco) equipped with an ultraviolet scanner and recorder was used. The initial density of the samples was $\rho_{23^{\circ}}=1.720 \mathrm{~g} / \mathrm{cm}^{3}$. Samples were centrifuged at $200,000 \times g$ for 24 to $48 \mathrm{~h}$ at $20^{\circ} \mathrm{C}$ either in the swing-out preparative rotor $\mathrm{SW}$ 50.1 or in the analytical Spinco rotor.

Base determinations from acid digests of DNA (28) were made as follows. Samples containing $1 \mathrm{mg}$ of DNA in $20 \mu \mathrm{l}$ of $70 \%$ perchloric acid were heated at $100^{\circ} \mathrm{C}$ for $1 \mathrm{~h}$, cooled, neutralized with $4 \mathrm{~N} \mathrm{KOH}$ in ice, and centrifuged. For descending chromatography, portions of supernatant samples were applied to $3 \mathrm{MM}$ Whatman paper (Balston, Maidstone, England), and a mixture of isopropanol-HCl-water $(170: 41: 39)$ was used as the solvent. The resultant spots, visualized under ultraviolet light at $253 \mathrm{~nm}$, were eluted with 0.1 $\mathrm{N} \mathrm{HCl}$, and the concentration of the bases was determined spectrophotometrically.

DNA hybridization. DNA was labeled by the "nick translation" procedure $(17,22)$. DNA samples $(1 \mu \mathrm{g} /$ $0.2 \mathrm{ml}$ ) in $50 \mathrm{mM} \mathrm{NaCl}, 5 \mathrm{mM}$ dithiothreithol, and 0.2 $\mathrm{M}$ Tris-hydrochloride buffer ( $\mathrm{pH}$ 7.4) were incubated with $7.5 \times 10^{-10} \mathrm{~mol}$ of unlabeled triphosphates of deoxythymidine and guanosine and $40 \mathrm{pmol}$ of $[\alpha-$ ${ }^{32} \mathrm{P}$ ]deoxycytidine triphosphate (The Radiochemical Center, Amersham, England). The reaction was started by the addition of deoxyribonuclease $\left(1.35 \times 10^{-4}\right.$ $\mu \mathrm{g})$ and DNA polymerase I $(2.45 \mu \mathrm{g})$. After $90 \mathrm{~min}$ at $20^{\circ} \mathrm{C}$, EDTA $\left(10^{-2} \mathrm{M}\right)$ was added, and DNA was phenol extracted and purified as described above, except that dialysis of ${ }^{32} \mathrm{P}$-labeled DNA against 0.1 mM EDTA plus $10 \mathrm{mM}$ Tris-hydrochloride buffer $(\mathrm{pH}$ 7.5) for $14 \mathrm{~h}$ at $4^{\circ} \mathrm{C}$ was included.

Unlabeled DNA in $0.9 \mathrm{M} \mathrm{NaCl}-0.09 \mathrm{M}$ sodium citrate buffer ( $\mathrm{pH} 7.6$ ) was denaturated by heating at $100^{\circ} \mathrm{C}$ for $5 \mathrm{~min}$ and quick cooling in melting ice and was filtered through nitrocellulose filters $(0.45-\mu \mathrm{m}$ pore size, type BA85; Schleicher-Schüll, Dassel, Germany; $20 \mu \mathrm{g}$ of DNA per 23-mm filter). The filters were repeatedly washed with the same buffer, dried overnight at $20^{\circ} \mathrm{C}$, and heated for $4 \mathrm{~h}$ at $80^{\circ} \mathrm{C}$.

The hybridization of labeled DNA to unlabeled nitrocellulose-bound DNA was performed essentially as described previously $(12,25)$. Filters with anchored DNA were placed in stoppered vials containing $1 \mathrm{ml}$ of $0.45 \mathrm{M} \mathrm{NaCl}$ plus $0.045 \mathrm{M}$ sodium citrate buffer $(\mathrm{pH}$ 7.6) to which Ficoll, polyvinyl pyrrolidone, and bovine serum albumin $(0.02 \%$, wt $/$ vol, each) were added. The vials were incubated for $4 \mathrm{~h}$ at $68^{\circ} \mathrm{C}$ before the hybridization reactions were started. The preincubation buffer was removed and was replaced with a sample of sonicated and heat-denatured ${ }^{32} \mathrm{P}-$ labeled DNA in $1 \mathrm{ml}$ of the same buffer; incubation was at $68^{\circ} \mathrm{C}$ for $24 \mathrm{~h}$. Filters were then removed, washed on both sides with $50 \mathrm{ml}$ of $3 \mathrm{mM}$ Tris-hydrochloride buffer ( $\mathrm{pH} 9.35$ ), air dried, and counted in a spectrometer with a scintillation fluid containing $4 \mathrm{~g}$ of Omnifluor (New England Nuclear Corp., Boston, Mass.) per liter of toluene.

Enzymes. Lysozyme (crystalline $N$-acetylmuramoyl-hydrolase from the whites of hens' eggs, 22,000 $\mathrm{U} / \mathrm{mg}$, EC 3.2.1.17), deoxyribonuclease I (deoxyribonucleate 5 '-oligonucleotidohydrolase from bovine pancreas, 2,000 U/mg, EC 3.1.4.5), and DNA polymerase I (deoxynucleoside triphosphate:DNA deoxynucleotidyltransferase from Escherichia coli MRE 600, 5,000 U/mg, EC 2.7.7.7) were obtained from Boehringer (Mannheim, Germany). Pronase (neutral proteinase from Streptomyces griseus, $100,000 \mathrm{U} / \mathrm{mg}$, EC 3.4.24.4) was from Serva Feinbiochemicals (Heidelberg, Germany), and ribonuclease A (from bovine pancreas crystalline ribonucleate 3 '-pyrimido-oligonucleotidohydrolase I, EC 3.1.4.22), from Sigma Chemical Co. (Saint Louis, Mo.).

\section{RESULTS}

Evaluation of the purification and analytical procedures. Preliminary to comparative analyses of the DNAs from the LDC, the DNA compositions of selected strains had to be assessed by both chemical and physical methods. In fact, contaminating polypeptides and polysaccharides are known to alter determinations of the buoyant density of DNA, as does the presence of unusual bases and base-bound hexoses. Indeed, in earlier studies in which shorter purification procedures were used, DNA samples with abnormally low $\mathrm{G}+\mathrm{C}$ contents were obtained by buoyant density determination in $\mathrm{CsCl}$. Purification by passage of the preparations through hydroxyapatite columns improved the quality of the final products. The data in Table 2 indicate that the corynebacterial DNA samples, which were prepared and purified by the method described above, yielded comparable $\mathrm{G}+\mathrm{C}$ values with both the chemical and physical methods of analysis. The results obtained with the reference corynebacteria were also consistent with those cited in the literature.

Base compositions of DNAs from LDC and reference corynebacteria. Purified DNAs from 25 selected LDC were analyzed by ultracentrifugation in $\mathrm{CsCl}$ gradients. The $\mathrm{G}+\mathrm{C}$ contents (by buoyant density) were within the range of 54 to 60 mol\% in most instances (Table 3). The values obtained by ultracentrifugation and base determination of acid hydrolysates were usually within $1 \mathrm{~mol} \%$ of each other. The values in Table 3 can be classified into three groups: (i) values between 57 and $60 \mathrm{~mol} \% \mathrm{G}+\mathrm{C}$ (more than half of the strains tested), (ii) values between 54 and 57 mol\% (about one-fourth of the strains), and (iii) values outside the 54 to $60 \mathrm{~mol} \%$ range (less than one-sixth of all the samples). The base compositions of the DNAs from the LDC strains are, therefore, similar to those ( 50 to $60 \mathrm{~mol} \% \mathrm{G}+\mathrm{C}$ ) of corynebacteria pathogenic for animals and dissimilar to those (60 to $70 \mathrm{~mol} \% \mathrm{G}+\mathrm{C}$ ) of corynebacterial parasites of plants.

Hybridization of DNA from LDC and reference corynebacteria. DNA homology among the LDC strains were tested by hybridization of DNA labeled by "nick translation" with unlabeled DNA anchored to nitrocellulose filters. Isologous hybridization values, which ranged between 20 and $30 \%$ of the input, were taken as $100 \%$ reference data. Results obtained by heterologous hybridization were calculated as $100 \%$ reference values. 
TABLE 2. Biophysical properties of DNAs from LDC and from reference corynebacteria

\begin{tabular}{|c|c|c|c|c|c|c|}
\hline \multirow{2}{*}{ Strain } & \multicolumn{3}{|c|}{ Absorbance $\left(A_{230-280}\right)^{a}$} & \multirow{2}{*}{$\begin{array}{l}\text { Buoyant density } \\
\qquad\left(\rho_{23^{\circ}}\right)^{h}\end{array}$} & \multirow{2}{*}{$\begin{array}{l}\text { Base composition } \\
\quad(\text { ATCG) }\end{array}$} & \multirow{2}{*}{$\underset{(\mathrm{mol} \%)}{\mathrm{G}+\mathrm{C} \text { content }^{d l}}$} \\
\hline & $A_{260}$ & $A_{260} / A_{230}$ & $A_{260} / A_{280}$ & & & \\
\hline $\begin{array}{l}\text { "Corynebacterium } \\
\text { hoffmannii"'e NCTC } 231\end{array}$ & 0.960 & 2.02 & 1.95 & 1.7156 & & 56.80 \\
\hline $\begin{array}{l}\text { Corynebacterium } \\
\text { xerosis NCTC } 9755\end{array}$ & 0.930 & 2.17 & 2.02 & 1.7178 & & 58.97 \\
\hline LDC6 & 0.750 & 2.11 & 2.02 & 1.719 & $\begin{array}{l}20.1,20.3 \\
29.9,29.7\end{array}$ & 59.72 \\
\hline LDC11 & 0.730 & 2.10 & 2.00 & 1.7182 & & 59.46 \\
\hline LDC14 & 1.020 & 2.08 & 1.97 & 1.7176 & $\begin{array}{r}19.9,21.7 \\
28.8,29.6\end{array}$ & 59.60 \\
\hline LDC20 & 0.980 & 2.07 & 2.00 & 1.7162 & $\begin{array}{l}21.6,21.7 \\
28.3,28.6\end{array}$ & 57.01 \\
\hline
\end{tabular}

${ }^{a}$ The level of contaminating proteins and ribonucleic acid (in all samples) was lower than the minimum amount detectable by the colorimetric procedure used (i.e., $1 \mu \mathrm{g} / 50 \mu \mathrm{g}$ of DNA per $\mathrm{ml}$ ).

${ }^{b}$ Buoyant density in $\mathrm{CsCl}$ gradient was estimated relative to that of virus $2 \mathrm{C}$ DNA (refractive index $\mathrm{RI}_{23^{\circ}}=$ 1.403 , buoyant density $\rho_{23^{\circ}}=1.742$ ).

${ }^{c}$ Base composition is in moles of adenine, thymine, guanine, and cytosine per $100 \mathrm{~mol}$ of total bases, by chromatography of acid hydrolysates.

${ }^{d} \mathrm{G}+\mathrm{C}$ content (percentage $\mathrm{G}+\mathrm{C}$ of total bases) was the average of the values obtained by buoyant density and spectrophotometric base determinations.

${ }^{e}$ Not on Approved Lists of Bacterial Names (23), not validly published since 1 January 1980, and hence without standing in bacterial nomenclature.

Data in Table 4 indicate that four of the reference LDC strains (LDC4, 8, 12, and 24) were very close to one another, as they exhibited 60 to $100 \%$ homology. More than half of the LDC strains in Table 4 were at least $50 \%$ homologous to these four reference strains. A few strains (LDC9, 11, and 15) were homologous to one another and yielded lower hybridization values with $\mathrm{LDC} 4,8,12$, and 24 . As a matter of fact, LDC15 displayed high $(>40 \%)$ homology with LDC9 and 11 and low $(<15 \%)$ homology with LDC4, 8, 12, and 24 (the latter LDC strains have homologies higher than $60 \%$ among themselves).

Accordingly, the LDC were divided into two homology clusters, one related to LDC8 and the other related to LDC15. In addition, as shown in Table 4, there was little homology (less than $10 \%$ in most instances) among the reference corynebacteria analyzed in the present study. Finally, among the reference organisms, Corynebacterium renale proved to be the closest to the LDC strains.

\section{DISCUSSION}

The difficulty in extracting high-molecularweight DNA from microorganisms of the genera Corynebacterium, Mycobacterium, and Nocardia (CMN group) has been emphasized repeatedly $(18,20,26,27)$. The difficulty stems from the nature and thickness of the cell wall of grampositive bacteria in general and of the $\mathrm{CMN}$ group in particular. In fact, methods for the mechanical disruption of bacteria (pressure cells of Hughes and French, high-speed shaking with glass beads, sonication, and grinding with abrasives) produce a fragmentation of DNA on the one hand, and on the other hand, organisms of the CMN group are relatively resistant to organic solvents and hydrolytic enzymes. Among the methods proposed for the preparation of DNA from CMN organisms are the use of lysozyme in the presence of glycine and EDTA to hydrolyze the peptidoglycan layer (20), incubation with pronase to digest the proteins of the envelope (6), and treatment with sodium deoxycholate in the presence of EDTA and Tween 80 to solubilize the cell wall (26). It was also suggested that the susceptibility of microorganisms to lysis relies on their growth phase, exponentially multiplying cells being easier to disrupt than stationary-phase cultures. We applied these procedures to the LDC and obtained an almost quantitative lysis when multiplying bacteria were submitted first to freezing-thawing and then to the lysozyme-EDTA treatment prior to extraction with sodium dodecyl sulfate and phenol.

Contamination of DNA preparations with polypeptides and polysaccharides is well known. The adverse effects of polysaccharide contaminants on the analysis of mycobacterial DNA has been stressed (24): high-molecularweight polysaccharides overlap the nucleic acid peaks in density gradient centrifugation, bind to polynucleotides in denaturation assays, and in- 
TABLE 3. Base compositions of DNAs from LDC and reference corynebacteria ${ }^{a}$

\begin{tabular}{|c|c|}
\hline Strain & $\begin{array}{c}\mathrm{G}+\mathrm{C} \text { content of DNA } \\
(\mathrm{mol} \%)\end{array}$ \\
\hline LDC1 $\ldots \ldots \ldots \ldots \ldots \ldots \ldots$ & 58.5 \\
\hline $\mathrm{LDC} 2 \ldots \ldots \ldots \ldots \ldots \ldots$ & 56.15 \\
\hline $\mathrm{LDC} 3 \ldots \ldots \ldots \ldots \ldots \ldots$ & 62 \\
\hline LDC $4 \ldots \ldots \ldots \ldots \ldots \ldots \ldots$ & 54.7 \\
\hline LDC6 $\ldots \ldots \ldots \ldots \ldots \ldots \ldots$ & 59.8 \\
\hline LDC8 $\ldots \ldots \ldots \ldots \ldots \ldots$ & 60 \\
\hline LDC $9 \ldots \ldots \ldots \ldots \ldots \ldots \ldots$ & 57.9 \\
\hline LDC10 $\ldots \ldots \ldots \ldots \ldots \ldots \ldots$ & 57.5 \\
\hline LDC11 $\ldots \ldots \ldots \ldots \ldots \ldots \ldots$ & 59.5 \\
\hline LDC12 $\ldots \ldots \ldots \ldots \ldots \ldots \ldots$ & 57.5 \\
\hline LDC14 . . . . . . . . . . . & 58.6 \\
\hline LDC15 $\ldots \ldots \ldots \ldots \ldots \ldots$ & 53 \\
\hline LDC16 $\ldots \ldots \ldots \ldots \ldots \ldots \ldots$ & 57 \\
\hline 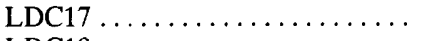 & 54 \\
\hline LDC18 $\ldots \ldots \ldots \ldots \ldots \ldots \ldots$ & 58.8 \\
\hline LDC19 . . . . . . . . . . . . & 59.1 \\
\hline LDC $20 \ldots \ldots \ldots \ldots \ldots \ldots$ & 56.7 \\
\hline $\mathrm{LDC} 21 \ldots \ldots \ldots \ldots \ldots \ldots$ & 55.6 \\
\hline $\mathrm{LDC} 22 \ldots \ldots \ldots \ldots \ldots \ldots$ & 54 \\
\hline LDC $23 \ldots \ldots \ldots \ldots \ldots \ldots$ & 52.5 \\
\hline LDC $24 \ldots \ldots \ldots \ldots \ldots \ldots$ & 58 \\
\hline LDC $25 \ldots \ldots \ldots \ldots \ldots \ldots$ & 62.2 \\
\hline $\begin{array}{l}\text { "C. herculis" }{ }^{\prime} \ldots \ldots \ldots \ldots \ldots \ldots \\
\text { NCIB } 9694\end{array}$ & 55 \\
\hline $\begin{array}{l}\text { C. renale } \ldots \ldots \ldots \ldots \ldots \ldots \ldots \ldots \\
\quad \text { NCTC } 7448\end{array}$ & 54 \\
\hline $\begin{array}{l}\text { "C. hoffmannii", } \ldots \ldots \ldots \ldots \ldots \ldots \\
\text { NCTC } 231\end{array}$ & 56.8 \\
\hline 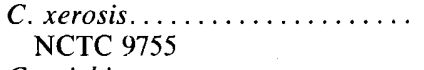 & 59 \\
\hline $\begin{array}{l}\text { C. michiganense } \ldots \ldots \ldots \ldots \ldots \\
\text { NCPPB } 1468\end{array}$ & 70.4 \\
\hline \multicolumn{2}{|c|}{$\begin{array}{l}{ }^{a} \text { Base composition established by buoyant density } \\
\text { determination and spectrophotometric analysis of } \\
\text { bases in DNA hydrolysates. The average value of } \\
\mathrm{G}+\mathrm{C} \text { (moles percent of total bases) is reported. } \\
{ }^{b} \text { Not on Approved Lists of Bacterial Names (23), } \\
\text { not validly published since } 1 \text { January } 1980 \text {, and hence } \\
\text { without standing in bacterial nomenclature. }\end{array}$} \\
\hline
\end{tabular}

terfere with hybridization experiments. Precipitation of DNA with alcohols, concentration with cetyltrimethyl ammonium bromide, and chromatography on poly-L-lysine Kieselguhr columns failed to remove completely polysaccharides from mycobacterial DNA (24). Both phenol and a chloroform-isoamyl alcohol mixture have been widely used for deproteinization of cell lysates, and isopropanol has been used for the selective precipitation of DNA; however, in the latter case, some RNA and polysaccharides are trapped in the DNA pellet upon centrifugation. In the case of corynebacteria, although the combined treatment with chloroform-isoamyl alcohol and phenol-lauryl sulfate removed most contaminating proteins, further purification of the DNA by chromatography on hydroxyapatite columns $(3,19)$ proved essential for elimination of residual polysaccharides and proteins from the LDC lysates. Indeed, the data in Table 2 indicate the high degree of purification of DNA prepared by the procedure described in the present work.

The taxonomy of the Actinomycetales remains a complex matter, in spite of the large number of chemical and immunological techniques which have been applied to it. The difficulties stem primarily from the extreme heterogeneity of the CMN group of bacteria, as proved by the very wide range of DNA base compositions $(50$ to $75 \mathrm{~mol} \% \mathrm{G}+\mathrm{C}$ ). This is particularly true for corynebacteria (50 to $70 \mathrm{~mol} \% \mathrm{G}+\mathrm{C}$ ), which have been divided into corynebacteria sensu stricto (50 to $60 \mathrm{~mol} \% \mathrm{G}+\mathrm{C}$ ) and the rhodochrous complex $(60$ to $70 \mathrm{~mol} \% \mathrm{G}+\mathrm{C})(5$, 9,30 ).

Even more striking is the taxonomic heterogeneity of the group of organisms referred to as "coryneforms," which includes members of the genera Arthrobacter, Brevibacterium, Cellulomonas, Corynebacterium, Erysipelothrix, Listeria, and Microbacterium (plus some members of the genera Mycobacterium and Nocardia). Bousfield (5) has published a dendrogram of coryneforms which showed 5 phena: most plantpathogenic corynebacteria were grouped in phenon $\mathrm{V}$, and phenon IV divided into a subphenum A (corynebacteria pathogenic for animals) and a subphenum B (Mycobacterium flavum).

In the present work, the DNAs of selected reference strains of true corynebacteria and of the rhodochrous complex were analyzed. In most cases our data (see Table 3) were reasonably close to those reported from other laboratories. (The base composition of $51 \mathrm{~mol} \% \mathrm{G}+\mathrm{C}$ previously reported for the DNA of " $C$. herculis" NCIB 9694, a name not on the Approved Lists of Bacterial Names [23], not validly published since 1 January 1980, and hence without standing in bacterial nomenclature, was not confirmed.) In addition, the $\mathrm{G}+\mathrm{C}$ contents of the DNAs from the majority of the LDC were found to lie within the range of 56 to $60 \mathrm{~mol} \%$, with an average value of $58 \mathrm{~mol} \%$. This value corresponds to that of the corynebacteria that are animal parasites, which possess the highest $\mathrm{G}+\mathrm{C}$ content.

Within the CMN group of bacteria, DNA homology has been used extensively in the classification of members of the genera Mycobacterium $(1,6,7,13,26)$ and Nocardia $(4,6,7)$ and the rhodochrous complex; however, little work has been devoted to the assessment, by DNA hybridization techniques, of the genetic relatedness of members of the corynebacteria pathogenic for animals (see 29, for example). The data in Table 4 indicate that there is little DNA 
TABLE 4. Hybridization of DNA from LDC and reference corynebacteria

\begin{tabular}{|c|c|c|c|c|c|c|c|c|c|c|}
\hline \multicolumn{11}{|c|}{ Percent hybridization of labeled DNA ${ }^{b}$} \\
\hline \multirow{2}{*}{ Unlabeled DNA ${ }^{a}$} & \multicolumn{7}{|c|}{ LDC } & \multicolumn{3}{|c|}{ Reference corynebacteria } \\
\hline & LDC-8 & LDC.24 & LDC-4 & LDC-12 & LDC-15 & LDC-20 & LDC-22 & $\begin{array}{l}\text { C. xerosis } \\
\text { NCTC } 9155\end{array}$ & $\begin{array}{c}\text { C. renale } \\
\text { NCTC } 7448\end{array}$ & $\begin{array}{c}\text { "C. hoffmannii" } \\
\text { NCTC } 231\end{array}$ \\
\hline LDC1 & 97.5 & 70.1 & 100 & 58.8 & 21.9 & 70.1 & 53.6 & 3.2 & 16.0 & 4.2 \\
\hline LDC2 & 68 & 34.7 & 87.4 & - & - & - & - & - & - & - \\
\hline LDC3 & 96.2 & 55.1 & 100 & 56.7 & 24.7 & 63 & 44.9 & 6.6 & 2.3 & 3.3 \\
\hline LDC4 & - & - & 100 & 61 & 10.2 & 76.9 & 50.6 & 6.6 & 16.5 & 4.2 \\
\hline LDC6 & 95.5 & 58.3 & \begin{tabular}{|l|}
77.1 \\
\end{tabular} & 73.6 & 16.8 & 54.4 & 43.1 & 5.4 & 16.0 & 4.1 \\
\hline LDC8 & 100 & 66.7 & 72.9 & 63.6 & 7.8 & 65.3 & 30 & 3.6 & 8.25 & 2.4 \\
\hline LDC9 & - & - & - & - & 40.8 & 100 & 67.2 & 14.1 & 35.6 & 9.6 \\
\hline LDC10 & 82 & 32.1 & 68.9 & 52.2 & 20.8 & 86.1 & 70.6 & 4.6 & 10.3 & 9.9 \\
\hline LDC11 & 65.4 & 46.2 & 61.55 & 66.3 & 43.5 & 88.7 & 76.7 & 10.7 & 36.3 & 8.2 \\
\hline LDC12 & 79.9 & 57.2 & 69.9 & 100 & 14.3 & 72.2 & 40.1 & 7.7 & 22.6 & 10.1 \\
\hline LDC15 & 1.9 & 0.9 & 3.1 & 25.2 & 100 & 27 & 22.8 & 6.8 & 15.4 & 5.3 \\
\hline LDC16 & 57.9 & 56.3 & 62.2 & 53.1 & 24.4 & 30.1 & 45.7 & 7.8 & 15.8 & 4.5 \\
\hline LDC17 & - & 23.7 & 79.6 & - & - & - & - & - & - & - \\
\hline LDC18 & 85.1 & 46.1 & 62.26 & 76.7 & 15.9 & 35.7 & 38.5 & 4.8 & 14.7 & 1.4 \\
\hline LDC20 & 72.4 & 40.3 & 100 & 68.8 & 17.0 & 100 & 32.9 & 5.3 & 17.2 & 4.1 \\
\hline LDC21 & 72 & 36.9 & 86.8 & 59.7 & 18.4 & 42.8 & 36.7 & 4.8 & 19 & 4.6 \\
\hline LDC22 & 63.4 & 26.4 & 31.8 & 34.4 & 15.0 & 31.2 & 100 & 1.0 & 0.9 & 6.0 \\
\hline LDC23 & 52.2 & 29.9 & 84.7 & 51.7 & - & 58.2 & 57.3 & 3.0 & 3.2 & 5.7 \\
\hline LDC24 & 75 & 100 & 64.5 & 68.5 & 7.6 & 36.1 & 29.2 & 3.5 & 8.15 & 2.5 \\
\hline LDC25 & 12.8 & 6.3 & 6.7 & 30.1 & 5.7 & 11.4 & 10.2 & 6.9 & 7.05 & 3.9 \\
\hline C. renale & - & - & - & - & 13.4 & 17.7 & 11.5 & 6.5 & 100 & 4.4 \\
\hline C. xerosis & - & - & - & - & 5.2 & 7.3 & 5.6 & 100 & 6.2 & 3.3 \\
\hline "C. hoffmannii'"c & - & - & - & - & - & 17.7 & 15.2 & - & - & 100 \\
\hline
\end{tabular}

${ }^{a}$ Unlabeled DNA anchored to nitrocellulose membrane.

'b DNA labeled by "nick translation" was hybridized to membrane-bound DNA. Hybridization is expressed as a percentage of the isologous annealing value taken as 100 .

${ }^{c}$ Not on Approved Lists of Bacterial Names (23), not validly published since 1 January 1980, and hence without standing in bacterial nomenclature.

homology among the corynebacteria, and this is true even for members of this genus which are animal parasites and which have similar $\mathrm{G}+\mathrm{C}$ contents in their DNAs. This observation agrees with those of previous studies which showed reduced immune cross-reactivity of ribosomes from corynebacteria $(15,16,21)$.

In contrast, there is a high degree of DNA homology among most members of the LDC (Table 4). The data in Table 4 indicate the existence of two homology clusters: most LDC belong to the LDC4, 8, 12, 24 cluster, and a minority of strains is related to the LDC15 cluster. The latter group displays some homology with $C$. renale. Consequently, if the proposal to divide the true corynebacteria into three groups (related to $C$. diphtheriae, $C$. genitalium, and $C$. renale) is adopted, it is in the last group that the LDC would be included.

It is concluded that the DNA base composition of the LDC clearly places these organisms with the true corynebacteria which are parasitic for animals. The homogeneity of the LDC group, as assessed in the present work by the $\mathrm{G}+\mathrm{C}$ content and the hybridization of the DNA, is currently being analyzed by chemical (cell wall components) and immunological (internal and external antigens) investigations.

\section{ACKNOWLEDGMENTS}

We gratefully acknowledge the financial support of the Belgian Ministry of Work " Cadre Spécial Temporaire" to P.D.), the Belgian National Science Foundation (P.H. is an established investigator of FNRS), and the $R$. Follereau Foundations ("les Amis du Père Damien" et "Gli Amici dei Lebbrosi"),

We are grateful for the assistance of $P$. Rensonnet in the ultracentrifugation analyses.

\section{REPRINT REQUESTS}

Address reprint requests to: C. Cocito, Department of Molecular Genetics, I.C.P. Ave Hippocrate 75, UCL 7449, B1200 Brussels, Belgium.

\section{LITERATURE CITED}

1. Baes, I., and M. Weis Bentzon. 1978. DNA hybridization between different species of mycobacteria. Acta Pathol. Microbiol. Scand. Sect. B 86:71-76.

2. Beaman, B. L., K. Kwang-Shin, M. A. Lanéelle, and L. Barksdale. 1974. Chemical characterization of organisms isolated from leprosy patients. J. Bacteriol. 117:13201329.

3. Bernardi, G. 1971. Chromatography of nucleic acids on hydroxyapatite columns. Methods Enzymol. 21:95-139.

4. Bouisset, L., J. Brueillaud, and G. Michel. 1963. Etude de l'ADN chez les actinomycétales: Comparaison entre les 
valeurs du rapport $\mathrm{A}+\mathrm{T} / \mathrm{G}+\mathrm{C}$ et les caractères bactériologiques de Corynebacterium. Ann. Inst. Pasteur Paris 104:756-770.

5. Bousfield, I. J. 1972. A taxonomic study of some coryneform bacteria. J. Gen. Microbiol. 71:441-455.

6. Bradley, S. G. 1973. Relationships among mycobacteria and nocardiae based upon DNA reassociation. J. Bacteriol. 113:645-651.

7. Bradley, S. G., G. H. Brownell, and J. Clarck. 1973. Genetic homologies among nocardiae and other actinomycetes. Can. J. Microbiol. 19:1007-1014.

8. Cocito, C. 1969 . Metabolism of macromolecules in bacteria treated with virginiamycin. J. Gen. Microbiol. 57:179194.

9. Crombach, W. H. J. 1978. DNA base ratios and DNA hybridization studies of coryneform bacteria, mycobacteria and nocardiae, p. 161-179. In I. J. Bousfied, and A. G Gallely (ed.), Coryneform bacteria. Academic Press, Inc., New York.

10. Delville, J. 1972. Considérations sur la multiplication de $M$. leprae et essais de culture. Acta Leprolog. 48/49:105111.

11. Delville, J., and A. M. Pichel. 1975. L'agent étiologique de la lèpre est-il invariablement acido-alcoolo résistant au Ziehl-Neelsen? Problèmes soulevés par les isolements à partir de lésions lépreuses de germes non acido-alcoolo résistants. Acta Leprolog. 59/60:83-91.

12. Gillespie, D., and S. Spiegelman. 1965. A quantitative assay for DNA-RNA hybrids with DNA immobilized on a membrane. J. Mol. Biol. 12:829-842.

13. Gross, W. M., and L. G. Wayne. 1970. Nucleic acid homology in the genus Mycobacterium. J. Bacteriol 104:630-634.

14. Janczura, E., M. Leyh-Bouille, J. M. Ghuysen, and C. Cocito. 1981. Structure of the peptidoglycans obtained from a group of corynebacteria. J. Bacteriol. 145:775-779.

15. Laub, R., J. Delville, and C. Cocito. 1978. Immunological relatedness of ribosomes from mycobacteria, nocardiae and corynebacteria, and microorganisms in leprosy lesions. Infect. Immun. 22:540-547.

16. Lind, A., and M. Ridell. 1976. Serological relationships between Nocardia, Mycobacterium, Corynebacterium and the "rhodochrous" taxon, p. 220-235. In M. Goodfellow, G. H. Brownell, and J. A. Serrano (ed.), The biology of the nocardiae. Academic Press. Inc., New York.

17. Mackey, J. K., K. H. Brackmann, M. R. Green, and M. Green. 1977. Preparation and characterization of highly radioactive in vitro labeled adenovirus DNA and DNA restriction fragments. Biochemistry 16:4478-4483.

18. Mandel, M., C. L. Schildkraut, and J. Marmur. 1968. Use of the $\mathrm{CsCl}$ density gradient analysis for determining the guanine plus cytosine content of DNA. Methods Enzymol. 12:184-195.

19. Markov, M., and I. G. Ivanov. 1974. Hydroxyapatite column chromatography in procedures for isolation of purified DNA. Anal. Biochem. 59:555-563.

20. Mizuguchi, Y., and T. Tokunaga. 1970. Method for isolation of deoxyribonucleic acid from mycobacteria. J. Bacteriol. 104:1020-1021.

21. Ridell, M. 1977. Studies on corynebacterial precipitinogens common to mycobacteria, nocardiae and rhodochrous. Int. Arch. Allergy Appl. Immunol. 55:847-875.

22. Rigby, P. W. J., M. Dieckmann, C. Rhodes, and P. Berg 1977. Labeling deoxyribonucleic acid to high specific activity in vitro by "nick translation" with DNA polymerase I. J. Mol. Biol. 113:237-251.

23. Skerman, V. D. B., V. McGowan, and P. H. A. Sneath (ed.). 1980. Approved lists of bacterial names. Int. J. Syst. Bacteriol. 30:225-420.

24. Tewfik, E. M. and S. G. Bradley. 1967. Characterization of deoxyribonucleic acids from streptomycetes and nocardiae. J. Bacteriol. 94:1994-2000.

25. Warnas, S. O., and J. A. Cohen. 1966. A quantitative assay for DNA-DNA hybrids using membrane filters. Biochem. Biophys. Res. Commun. 24:554-558.

26. Wayne, L. G., and W. M. Gross. 1968. Isolation of deoxyribonucleic acid from mycobacteria. J. Bacteriol. 95:14811482 .

27. Wayne, L. G., and W. M. Gross. 1968. Base composition of DNA isolated from mycobacteria. J. Bacteriol. 96:1915-1919.

28. Wyatt, G. R. 1955. Separation of nucleic acid components by chromatography on filter paper, p. 243-265. In E. Chargaff and J. N. Davidson (ed.), The nucleic acids, chemistry and biology, vol. 1. Academic Press, Inc., New York.

29. Yamada, K., and K. Komagata. 1970. Taxonomic studies on coryneform bacteria. 3. DNA base composition of coryneform bacteria. J. Gen. Appl. Microbiol. 16:215224.

30. Yamada, K., and K. Komagata. 1972. Taxonomic studies on coryneform bacteria. V. Classification of coryneform bacteria. J. Gen. Appl. Microbiol. 18:417-431. 